\title{
Analysis of the Structure of Job Offers on the Czech Labour Market
}

\section{Tomáš Martínek ${ }^{1}$, Petr Hanzlík ${ }^{2}$}

\begin{abstract}
Labour market development is an important macro-economic indicator of every national economy. Labour supply in particular fields should reflect on demands of employers on newly recruited employees. These demands can be analysed by studying published job offers. This analysis of Czech labour market is conducted based on the aggregated statistical data collected by an on-demand application. The studied data sample covers more than $60 \%$ of all the job offers published in the Czech Republic. The situation in respective occupational fields is compared with aggregate nation-wide average as well as with data from other fields. Results show distinct differences in absolute quantity of offers, compensations to employees offered as well as qualification requirements.
\end{abstract}

Key words: Job offers, labour market, job search, Czech Republic, Employment Statistics

JEL Classification: J32, J23

\section{Introduction}

The Czech Republic has an open, exported-oriented economy and so the situation on its labour market is highly dependent on the world economy, and EU and Germany in particular. The demand on these markets is a significant determinant of employer's requirements in the Czech Republic. In order to understand the dynamics of the labour demand and to get insights about what potential employees can expect to see in published vacant positions, and which qualities can help them apply for them successfully, it is important to study job offers, their structure across various occupational fields, and their representative characteristics. Knowing these, efficient strategies for education and employability can be tailored, which can have a positive impact on the highly problematic group of unemployed people younger than 25 , where the unemployment rate is significantly higher than the average unemployment rate of the EU as a whole (Jansen 2013).

\footnotetext{
${ }^{1}$ Department of Information Engineering, Faculty of Economics and Management, Czech University of Life Sciences Prague, Kamýcká 129, 16521 Prague 6, Czech Republic, E-mail: martinekt@pef.czu.cz

2 Department of Information Engineering, Faculty of Economics and Management, Czech University of Life Sciences Prague, Kamýcká 129, 16521 Prague 6, Czech Republic, E-mail: hanzlik@pef.czu.cz
} 
To gather this desirable information, an on-demand application that aggregates the job offers from multiple sources, including the Czech Labour Office and several private personnel agencies and job portals has been created by the authors of this research. This article analyses collected job offers properties, and studies the development tendencies in 15 basic occupational areas, including agriculture and forestry. Characteristics of the vacant positions are discussed with special emphasis to qualification requirements and suitability for several interest groups of employees. It also analyses the type of contract required, working hour structure and compensation to employees offered.

In the past decades, economies in Europe have undergone a deep restructuring, Czech Republic being no exception. The admission into the European Union lead to implementation of several European treaties into the local legislation aiming to support the integration among EU countries, which has been the driving force behind most of the recent changes. These affected the labour market in a way which further supported the significant outflow of labour from agriculture, followed by the declining interest in the field as a whole among the workforce. Several policies have been tailored and applied to agriculture, including the EU Common Agricultural Policy (CAP), to provide farmers with a reasonable standard of living. These farm subsidies have reduced the outflow of labour from rural areas; however, researchers have shown that this policy has not halted the outflow in a long-term perspective (Tocco, Davidova, Bailey, 2012). Imperfect functioning of rural labour market has been pointed out as one of the key problems at hand. This leads to a sub-optimal allocation of labour and thus to lower income of workers in agriculture. For tailoring the agricultural policies, it is thus crucial to gain the understanding of factor markets and the functioning of the labour market in particular.

The agricultural labour market is specific in many ways, especially concerning the dominant rural characteristic of the field in comparison with industry and services. In order to understand processes that take place on the agricultural labour market, it is vital to recognize the aggregate labour market framework, and describe the most important variables which govern the rural labour markets specifically. Teagasc (2011) classifies these variables into three essential groups: Structure of the labour, legal framework and regulations that govern the rural labour market, and the different policies that influence the labour market. For further schematics, labour market can be differentiated into the supply and demand side, according to the neoclassical economic theories.

Let us first present a few general assumptions about the supply side, in other words, the available labour. As has already been mentioned before, agricultural activities are pursued mainly in rural areas, which severely restricts residential choices (Johnson, 1991). This in turn reduces both the cross-sector employment chance and mobility in general (Hodge et al 2002). When compared to other sectors, many studies have pointed out the high age of workers in agriculture (Bojnec et al., 2003; Bojnec and Dries, 2005; Van Herck, 2009), as well as low level of education attained, with a significant proportion of the population having no more than primary education. The quality of human capital of agrarian sector is thus considered low (Goodwin and Holt, 2002).

The amount of demanded labour is associated with several employer-describing variables too. One of the key differences among the employers is hidden in the organisational structure, often expressed by the term dual farm structure (Schnicke et al., 2007). It classifies farms into two categories - small family farms, and large, factory-style corpo- 
rate farms. The way how these two types of units operate is typically significantly different - the family farms extensively rely on family labour, while the corporate farms utilize hired labour entirely.

Production season of agricultural activities pursued is another determinant of the amount of labour demanded. During harvest, many fields of agriculture, like fruit growing, still rely on manpower rather than on machinery. This way, an employee can be employed on several agricultural activities throughout the year. The increase in the share of seasonal wage labour, however, corresponds not only to an increase in intraannual fluctuations of agricultural activity, but also to changes in manpower management due to competition growing more severe and due to pressure on cutting costs (Darpeix, Bignebat, Perrier-Cornet, 2014). Based on this, the high demand for seasonal wage labour can be expected, in comparison with industry and service sector.

The demand side of the labour market is similarly characterised and affected by social context (Uzzi 1997; Atterton 2007). The rural nature of agricultural activities once again proves to be a problem because of the low population density in such areas, which limits the available set of suitable candidates to fill in a vacancy (de Hoyos; Green, 2011). In the long term, agricultural entrepreneurs thus often struggle with positions that are difficult to fill.

This paper presents a factual framework of the Czech Labour market, and studies how the employers in general utilize the labour portals for hiring the employees; special emphasis is put on agriculture, here. Based on the dataset collected, the work analyzes the structure of so represented agricultural labour demand in comparison with other fields. Based on these findings, the propensity of labourers to be attracted by such offers is discussed.

The main goal of this article is to provide a comprehensive analysis of job offers in the Czech Republic, conducted on almost one-year long dataset of panel data collected from November 23, 2012 to July 16, 2014. In order to provide an annual comparison of selected characteristics, this data is further supported by the cross-sectional data from December 10, 2013. This article is mainly based on this primary dataset which has been gathered by the web application Nabidka-prace.czin.eu, created by the authors. This paper further outlines the possibilities of the real time job offers analysis and its benefits for understanding the labour market dynamics.

\section{Materials and Methods}

Czech labour market is a place of interaction among several entities. Besides the essential ones - job applicants and employers, only a few other intermediaries exist. The legislation explicitly defines the existence of the Labour Office, an institution which has a duty to register vacant positions offered by employers, as well as potential workforce registered at the Labour Office (CR 2011, CR 2004). In addition to this channel, there are personnel agencies (also referred to as staffing agencies) which can help companies find suitable candidates for vacant positions advertised. Personnel agencies can be financed within the scope of shared employment mediation from the national budget since 2012 (CR 2011). The personnel agency manages its own evidence of workforce and registers vacant positions as provided by employers cooperating with it. Online job 
portals are yet another group of players active on the Czech labour market. These portals enable public to access vacant position offers stored in their database throughout a web interface. The personal agencies often run their own job portals. Most of the independent online job portals utilize a model, where both the personnel agencies and individual employees can place their demands.

The web application Nabidka-práce.czin.eu, the main source of data in this research, is thus de facto a job portal which aggregates job-offers available from the Czech Labour Office, private personal agencies, and individual employers. By comparing the statistics of the Ministry of Labour and Social Affairs and the amount of the data collected, it processes more than $60 \%$ of all the job offers published in the Czech Republic. To demonstrate this in absolute values, the Ministry of Labour and Social Affairs registered 35,178 of the vacant job positions as of December 13, 2013. In comparison, this study registered 30,077 vacant job positions on the same day, listed in 15,923 individual job offers.

The application is based on integrating the job-offers' metadata using XML. The job offers collected have been further classified to 15 categories, following the basic categories used at the web portal of the Czech Labour Office. Every investigated job offer thus must be assigned to one of the corresponding classes: Administration, Traffic, Finances, IT, Legal Services, Culture and sport, Management, Business and tourism, Defence and protection, Civil engineering, Research and development, Training and education, Production and manufacturing, Healthcare, Agriculture and forestry. Most of the data sources used, however, enable classification of a job offer to more than one category. According to the analysed data set, less than $20 \%$ of all the offers are of such a character. Annual comparison of cross-sectional observations from December 10, 2012, and December 10, 2013, is provided to foreshadow the longitudinal tendencies on the market.

When analysing compensations paid to employees, it is crucial to realize one feature of job offers: Starting wage is often specified as an interval. This article operates with this assumption and creates an interval overview of offered salaries, too, by introducing three basic terms - average minimum salary, average salary, and average maximum salary. The average minimum salary was calculated as an average of salaries listed as a minimal offering. The average maximal salary has been calculated as the average upper boundary of salaries listed with a maximum starting salary. The average salary has eventually been calculated as the average of upper and lower boundary of the salary interval in relevant cases. The minimum salary is available in circa $90 \%$ of the job offers, while the average and maximum salary achievable is announced in over $40 \%$ of all the job offers analysed.

As far as methodical basis of this article is concerned, it uses quantitative data analysis where the main emphasis is placed on categorical distribution of data in individual categories and annual change comparison. The obtained data of the panel character has thus been studied both from the long-term development point of view and from the categorical contribution to the aggregate image. 


\section{Analysis of Job Offers}

This paper thoroughly analyses the workforce demand in the Czech Republic as represented by the previously specified dataset. To put this study into the labour market reference frame, let us first present the official statistics showing the development of the total unemployment in last three years related to the official number of the vacant job positions, as presented by the Ministry of Labour and Social Affairs (MoLSA).

Figure 1 Unemployment and Vacant Positions Statistics 2011-2014 (With Annual Data from December)

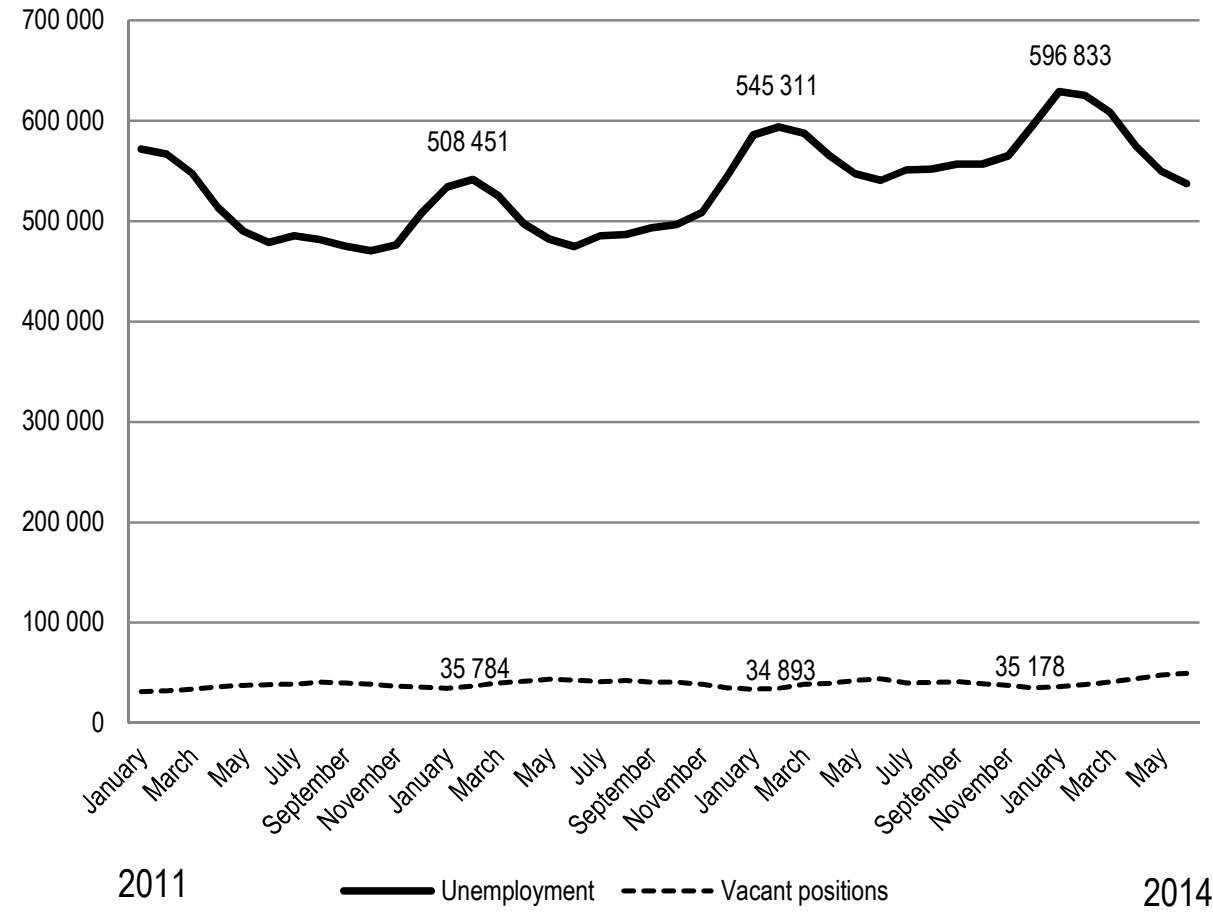

Source: MoLSA Integrated portal

To understand the nature of vacant positions further, let us split it now into individual categories according to general occupational field. Relative representations of most common of them are presented in the following graph. In the fourth quarter of 2013, the unemployment rate of the population in productive age (i.e. between 15 and 64 years) was $6.8 \%$ in the Czech Republic, which is the sixth lowest figure to be found among the EU countries; the EU average being 10.7\% (CSO 2014). 
Figure 2 Vacant Job Positions by Categories

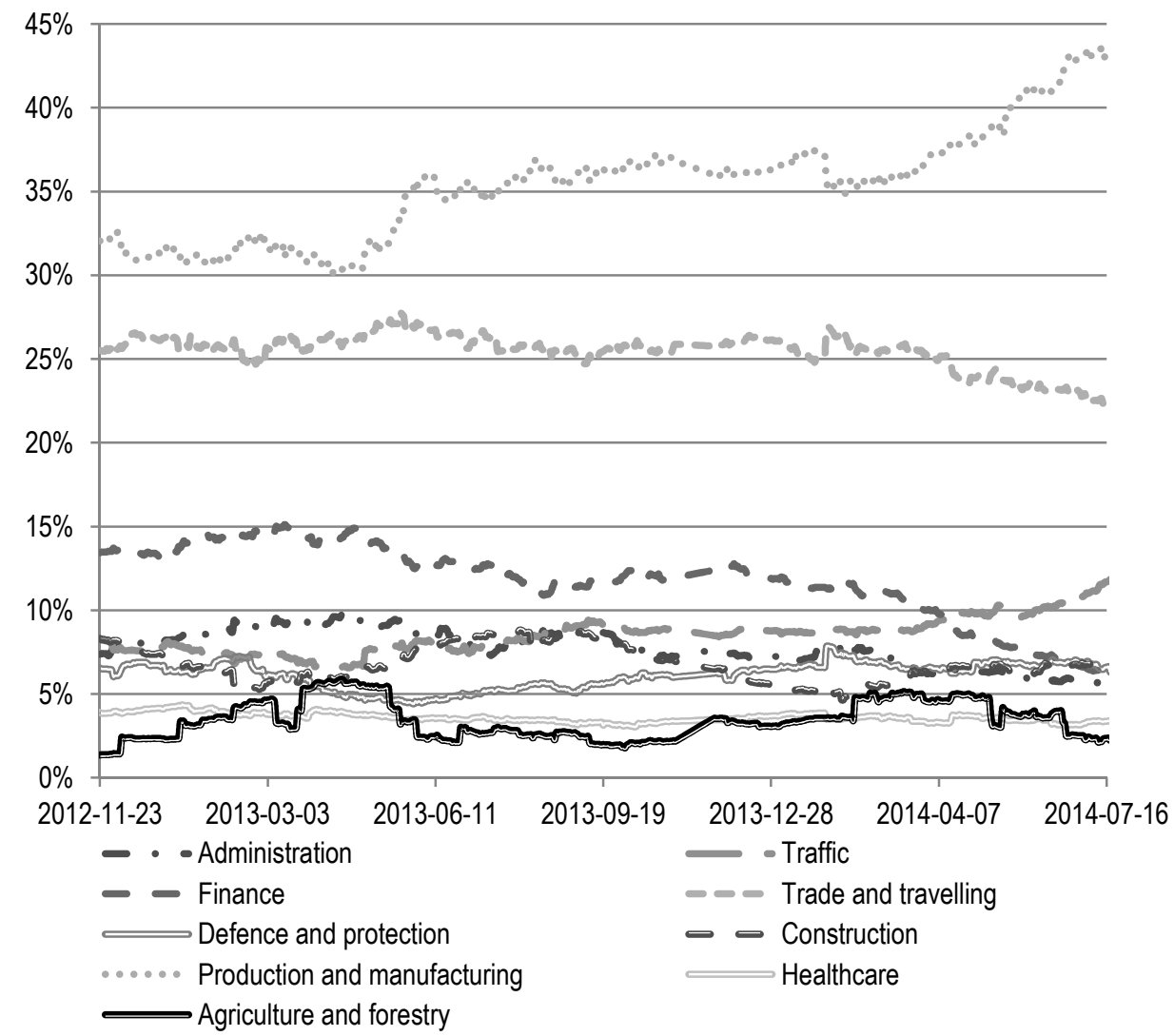

Source: Own work.

As has already been mentioned in the section discussing the materials used, approximately one fifth of offers can be categorised to more than one group. If we were to sum up these relative shares, we would conclude that the result would exceed 100. The share of vacant job position in the prominent category, "production and manufacturing", is gradually increasing, having reached $35 \%$ in the December 2013. This can correspond to the increasing performance of the Czech economy in the last two quarters of 2013. The second category listed as "trade and travelling" is stable in the period under observation, with its share fluctuating just above $25 \%$. On the other hand, the relative share of offers in "finances" gradually declines, yet remains above $10 \%$. Administration, traffic, construction, and defence and protection are the remaining categories broadly desired by employees, with each represented in more than $5 \%$ of all the job offers. The number of vacant positions in agriculture and forestry reaches above this line only in the spring, corresponding to the obvious seasonal character of the field. These data are further differentiated by the contract types. 
Table 1 Vacant Job Positions by Contract Type and Job Category

\begin{tabular}{l|cccccc}
\hline & \multicolumn{3}{|c}{ Full time } & \multicolumn{2}{c}{ Part time } & \multicolumn{2}{c}{ Fixed-term } \\
\hline Administrative & $92.56 \%$ & $0.32 \%$ & $6.22 \%$ & $-7.44 \%$ & $1.21 \%$ & $19.85 \%$ \\
Traffic & $95.57 \%$ & $-0.74 \%$ & $2.91 \%$ & $-1.67 \%$ & $1.52 \%$ & $99.58 \%$ \\
Finance & $79.10 \%$ & $-11.15 \%$ & $18.60 \%$ & $153.61 \%$ & $2.30 \%$ & $-36.77 \%$ \\
Information Technologies & $91.60 \%$ & $-5.38 \%$ & $7.35 \%$ & $199.84 \%$ & $1.05 \%$ & $42.78 \%$ \\
Legal services & $96.67 \%$ & $-3.33 \%$ & $0.00 \%$ & - & $3.33 \%$ & - \\
Culture a sport & $53.45 \%$ & $-3.25 \%$ & $44.48 \%$ & $2.15 \%$ & $2.07 \%$ & $71.03 \%$ \\
Management & $90.20 \%$ & $14.28 \%$ & $8.66 \%$ & $-57.44 \%$ & $1.14 \%$ & $57.39 \%$ \\
Trade and travelling & $84.64 \%$ & $-3.43 \%$ & $13.70 \%$ & $28.45 \%$ & $1.64 \%$ & $-2.78 \%$ \\
Defence and protection & $80.77 \%$ & $-1.03 \%$ & $17.31 \%$ & $-0.64 \%$ & $1.92 \%$ & $98.72 \%$ \\
Construction & $92.28 \%$ & $-4.00 \%$ & $6.67 \%$ & $133.87 \%$ & $1.06 \%$ & $3.12 \%$ \\
Research and development & $99.12 \%$ & $-0.88 \%$ & $0.88 \%$ & - & $0.00 \%$ & - \\
Education & $81.03 \%$ & $-3.38 \%$ & $18.53 \%$ & $25.69 \%$ & $0.43 \%$ & $-68.82 \%$ \\
Production and manufacturing & $95.44 \%$ & $-2.28 \%$ & $3.49 \%$ & $101.80 \%$ & $1.07 \%$ & $76.72 \%$ \\
Healthcare & $96.44 \%$ & $0.49 \%$ & $2.33 \%$ & $15.61 \%$ & $1.23 \%$ & $-38.79 \%$ \\
Agriculture and forestry & $96.37 \%$ & $0.60 \%$ & $3.63 \%$ & $29.36 \%$ & $0.00 \%$ & $-100.00 \%$ \\
\hline Czech Rep. In total & $90.39 \%$ & $-2.11 \%$ & $8.25 \%$ & $28.75 \%$ & $1.36 \%$ & $7.94 \%$ \\
\hline Source: $O$ mwn & & & & & & \\
\hline
\end{tabular}

Source: Own work.

Over $90 \%$ of all the vacant job positions are contracted as full time jobs. This signifies the annual decrease of more than $2 \%$. The category of finances, where the decline reaches $11 \%$, is the most significant contributor to this tendency. The fixed term contracts, or contracts with the freelancers and contractors are generally preferred over the full-time job agreements. These contractors are often self-employed or are part of other companies.

According to a study carried out by European Trade Union Institute (ETUI), this shift in demand for alternative employment contracts can be an interesting identifier of influence of the world economic crisis. This approach is based on the assumption that the most significant increase in the number of employment contracts different than full-time happens in economies where the impact of the global economic crisis is strongest (Leschke 2012). 


\section{Monthly Compensations Offered to Employees}

The average salary in the Czech Republic is in a long run subjected to the both directional fluctuation. The long-term development of the average salaries is presented in the following figure:

Figure 3 The Average Salary in the Czech Republic by Gender (in CZK)

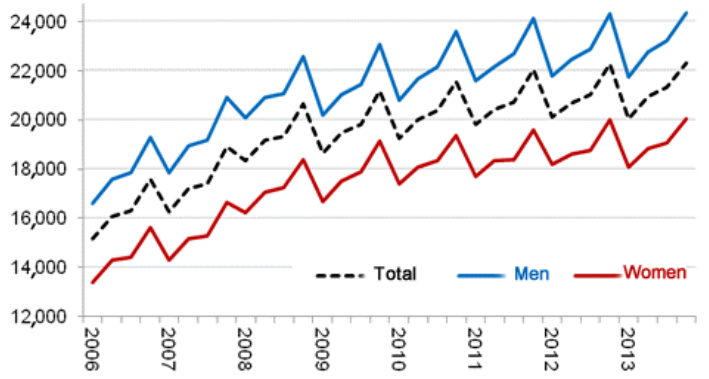

Source: CSO (2014)

Figure 4 Overview of Compensations to Employees in CZK as Occurring in Job Offers Processed

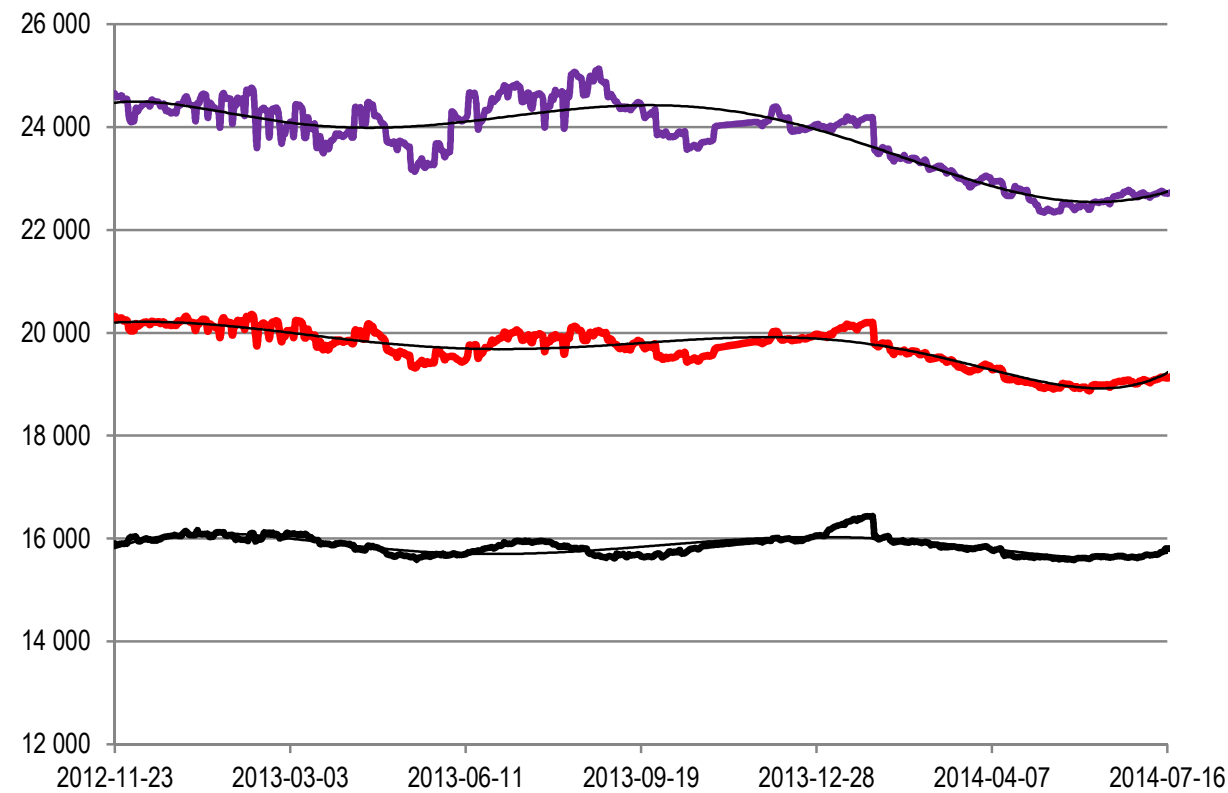

\footnotetext{
Average minimal compensation to employees Average maximal compensation to employees
}

Average compensation to employees

Source: Own work. 
Figure 4 represents the development in compensation to employees as they occurred in the job offers analysed. In order to understand this figure, it is important to recall that in many cases, job offers contain starting salaries specified as an interval rather than as a single value. Therefore, the figure clearly shows that while the average minimum offered is stable and fluctuating around $16,000 \mathrm{CZK}$, the maximum boundary is much more volatile and declining in the long term. In average, the starting salary offered by employers thus moves just below $20,000 \mathrm{CZK}$. It is also interesting to note both the average minimum and the total average in agriculture and forestry lies deep below the country's average.

The situation in individual occupation categories is presented in a greater detail in the following table.

Table 2 Compensation Offered to Employees by Domain, including Annual Comparison

\begin{tabular}{|c|c|c|c|c|c|c|c|c|}
\hline \multirow[t]{2}{*}{ Field } & \multicolumn{2}{|c|}{ Job offers share } & \multicolumn{2}{|c|}{$\begin{array}{l}\text { Average minimal } \\
\text { compensation to } \\
\text { employees }\end{array}$} & \multicolumn{2}{|c|}{$\begin{array}{l}\text { Average compensa- } \\
\text { tion to employees }\end{array}$} & \multicolumn{2}{|c|}{$\begin{array}{l}\text { Average maximal } \\
\text { compensation to } \\
\text { employees }\end{array}$} \\
\hline & $\%$ & $\begin{array}{l}\text { Annual } \\
\text { change }\end{array}$ & CZK & $\begin{array}{l}\text { Annual } \\
\text { change }\end{array}$ & CZK & $\begin{array}{l}\text { Annual } \\
\text { change }\end{array}$ & CZK & $\begin{array}{l}\text { Annual } \\
\text { change }\end{array}$ \\
\hline Administrative & $7.29 \%$ & $-7.13 \%$ & 16,173 & $0.85 \%$ & 19,954 & $4.17 \%$ & 23,787 & $5.92 \%$ \\
\hline Traffic & $8.84 \%$ & $16.26 \%$ & 17,234 & $4.50 \%$ & 20,679 & $-0.39 \%$ & 24,002 & $0.10 \%$ \\
\hline Finance & $12.30 \%$ & $-9.51 \%$ & 18,306 & $-0.28 \%$ & 25,248 & $5.57 \%$ & 30,378 & $0.71 \%$ \\
\hline Information technologies & $1.65 \%$ & $-36.89 \%$ & 23,997 & $1.97 \%$ & 29,812 & $0.07 \%$ & 36,989 & $1,24 \%$ \\
\hline Legal services & $0.23 \%$ & $-40.43 \%$ & 18,158 & $4.63 \%$ & 20,830 & $-2.50 \%$ & 24,727 & $-2.13 \%$ \\
\hline Culture a sport & $1.73 \%$ & $43.31 \%$ & 12,451 & $-4.10 \%$ & 17,099 & $-16.85 \%$ & 20,165 & $-19.61 \%$ \\
\hline Management & $2.38 \%$ & $-29.02 \%$ & 24,576 & $8.90 \%$ & 31,047 & $4.20 \%$ & 38,222 & $7.74 \%$ \\
\hline Trade and travelling & $26.22 \%$ & $0.34 \%$ & 14,772 & $0.00 \%$ & 19,657 & $-1.77 \%$ & 24,163 & $-3.45 \%$ \\
\hline Defence and protection & $6.41 \%$ & $-5.43 \%$ & 9,628 & $6.26 \%$ & 11,648 & $2.71 \%$ & 13,590 & $4.48 \%$ \\
\hline Construction & $5.89 \%$ & $-23.72 \%$ & 15,195 & $1.27 \%$ & 17,705 & $4.49 \%$ & 21,040 & $6.12 \%$ \\
\hline $\begin{array}{l}\text { Research and Develop- } \\
\text { ment }\end{array}$ & $0.45 \%$ & $-5.76 \%$ & 25,847 & $11.61 \%$ & 34,768 & $24.66 \%$ & 41,443 & $5.27 \%$ \\
\hline Education & $1.28 \%$ & $-6.95 \%$ & 15,872 & $0.64 \%$ & 18,008 & $1.28 \%$ & 20,982 & $0.13 \%$ \\
\hline $\begin{array}{l}\text { Production and manu- } \\
\text { facturing }\end{array}$ & $36.10 \%$ & $15.98 \%$ & 16,137 & $-1.45 \%$ & 19,248 & $-1.80 \%$ & 22,850 & $0.39 \%$ \\
\hline Healthcare & $3.54 \%$ & $-10.52 \%$ & 19,996 & $2.40 \%$ & 22,852 & $-5.01 \%$ & 27,166 & $-6.97 \%$ \\
\hline Agriculture and forestry & $3.22 \%$ & $34.24 \%$ & 13,388 & $4.90 \%$ & 15,178 & $2.59 \%$ & 17,622 & $-49.42 \%$ \\
\hline Czech Rep. In Total & $100 \%$ & - & 15,996 & $0.03 \%$ & 19,879 & $-1.62 \%$ & 23,967 & $-1.98 \%$ \\
\hline
\end{tabular}

Source: Own work.

Like in the majority of the world (Van Der Hoeven 2010), the difference in the level of income among individual fields is increasing. The average starting salary offered is naturally significantly higher in the high-income domains, such as research and devel- 
opment, management, or finances, and it still experiences quite a significant growth. As far as the minimum average is concerned, compensations to employees seems to grow significantly especially in the categories which are below the long-term national average, like culture and sport, and agriculture and forestry.

\section{Specific Groups of Job Applicants}

When analysing labour demand, it is also important to differentiate individual offers according to their target group; such as by jobs suitable for foreign nationals, or for disabled people. The following figure, categorized by the occupation field, presents the statistics of foreign workforce.

Figure 5 Amount of Foreign Nationals Employed in the Czech Republic by Categories of Economic Activities

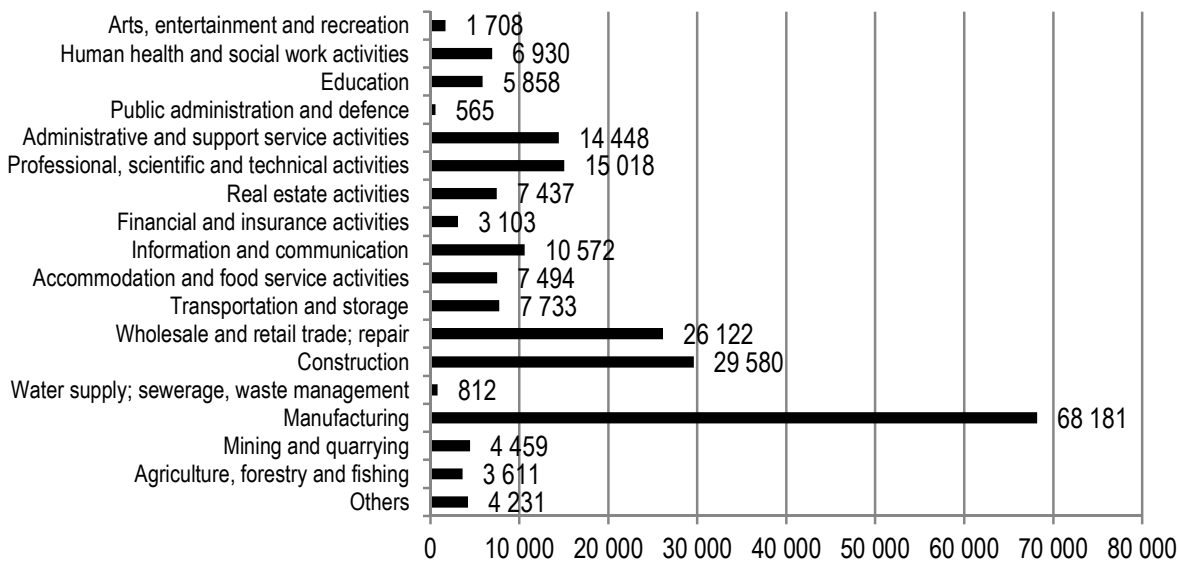

Source: CSO (2012)

The aggregate numbers from the Czech Statistical Office can again serve as a reference, when analysing the data gathered by our application, as presented in the following table.

Most of the offers suitable for foreign nationals in the Czech Republic have been identified in the fields of information technologies, research and development, education, agriculture and forestry, healthcare, legal services, and construction. Overall, it thus covers approximately $5 \%$ of job offers, which represent a significant annual drop of more than $16 \%$. A crucial difference is also in the salaries offered. While in the fields where companies mostly demand highly qualified specialists (like IT, management, administration, finances, healthcare, or research and development) salaries offered exceed the nation-wide average, whereas in occupations classified as construction, education, or agriculture and forestry, the salaries offered were significantly lower. The correlation between the starting salary and the desired specialization including the level of education seems to be a reasonable hypothesis. The total amount of offers in agriculture 
and forestry suitable for foreign nationals has also significantly decreased in an annual comparison.

Table 3 Job Offers Suitable for Foreign Nationals and Disabled People, Categorized by Fields of Occupation

\begin{tabular}{l|cccccc}
\hline & Foreigners & $\begin{array}{c}\text { Annual } \\
\text { Change }\end{array}$ & $\begin{array}{c}\text { Average minimum } \\
\text { salary }\end{array}$ & $\begin{array}{c}\text { People } \\
\text { with a } \\
\text { disability }\end{array}$ & $\begin{array}{c}\text { Annual } \\
\text { Change }\end{array}$ & $\begin{array}{c}\text { Average mini- } \\
\text { mum salary }\end{array}$ \\
\hline Administrative & $5.06 \%$ & $-34.08 \%$ & 31,663 & $17.91 \%$ & $27.10 \%$ & 11,020 \\
Traffic & $6.20 \%$ & $-20.72 \%$ & 16,505 & $3.81 \%$ & $42.56 \%$ & 11,543 \\
Finance & $3.36 \%$ & $-3.25 \%$ & 35,373 & $10.36 \%$ & $22.94 \%$ & 16,761 \\
Information technol- & $22.30 \%$ & $-3.50 \%$ & 38,066 & $13.65 \%$ & $79.63 \%$ & 18,826 \\
ogies & $8.62 \%$ & $-61.33 \%$ & 38,500 & $8.33 \%$ & $61.11 \%$ & 15,638 \\
Legal services & $10.48 \%$ & $-1.33 \%$ & 17,193 & $6.90 \%$ & $71.03 \%$ & 7,844 \\
Culture a sport & $11.34 \%$ & $-0.55 \%$ & 41,537 & $3.76 \%$ & $43.65 \%$ & 22,179 \\
Management & $3.46 \%$ & $-5.04 \%$ & 21,103 & $7.44 \%$ & $26.79 \%$ & 10,331 \\
Trade and travelling & $0.65 \%$ & $-20.51 \%$ & 6,000 & $59.87 \%$ & $21.31 \%$ & 8,975 \\
$\begin{array}{l}\text { Defence and protec- } \\
\text { tion }\end{array}$ & $7.87 \%$ & $-39.48 \%$ & 13,210 & $1.90 \%$ & $-16.48 \%$ & 11,680 \\
$\begin{array}{l}\text { Construction } \\
\text { Research and }\end{array}$ & $19.39 \%$ & $4.98 \%$ & 39,320 & $9.73 \%$ & $90.80 \%$ & 22,892 \\
$\begin{array}{l}\text { Development } \\
\text { Education }\end{array}$ & $18.89 \%$ & $-38.40 \%$ & 14,822 & $8.19 \%$ & $255.43 \%$ & 13,476 \\
$\begin{array}{l}\text { Production and } \\
\text { manufacturing }\end{array}$ & $5.77 \%$ & $-17.22 \%$ & 18,668 & $7.07 \%$ & $25.51 \%$ & 11,253 \\
$\begin{array}{l}\text { Healthcare } \\
\text { Agriculture and } \\
\text { forestry }\end{array}$ & $9.48 \%$ & $51.47 \%$ & 22,706 & $3.69 \%$ & $-19.66 \%$ & 14,359 \\
\hline Czech Rep. In Total & $11.21 \%$ & $-30.70 \%$ & 10,429 & $4.66 \%$ & $149.48 \%$ & 9,678 \\
\hline Source: Own work. & $5.07 \%$ & $-16.32 \%$ & 24,140 & $10.72 \%$ & $27.69 \%$ & 11,604 \\
\hline
\end{tabular}

Source: Own work.

The disabled are another specific group in the workforce. In total, over $10 \%$ of presented job offers were suitable for them, which mark a significant increase in such a type of offers with annual increase of over $27 \%$. It can be safely assumed that this is the result of the Czech subsidy policy. In spite of that, the average salary offered remains deep under the nation-wide average.

\section{Education}

Besides following the characteristics which determine the actual desirability and availability of a vacant position, it is important to study the characteristics that employers require from job candidates. Such information is especially useful when trying to find out what is the potential gap between the capabilities of available workforce and employers' needs. The following graph describes the desired structure of education within presented job offers. 
Figure 6 Requirements for Level of Education Attained within Positions Offered

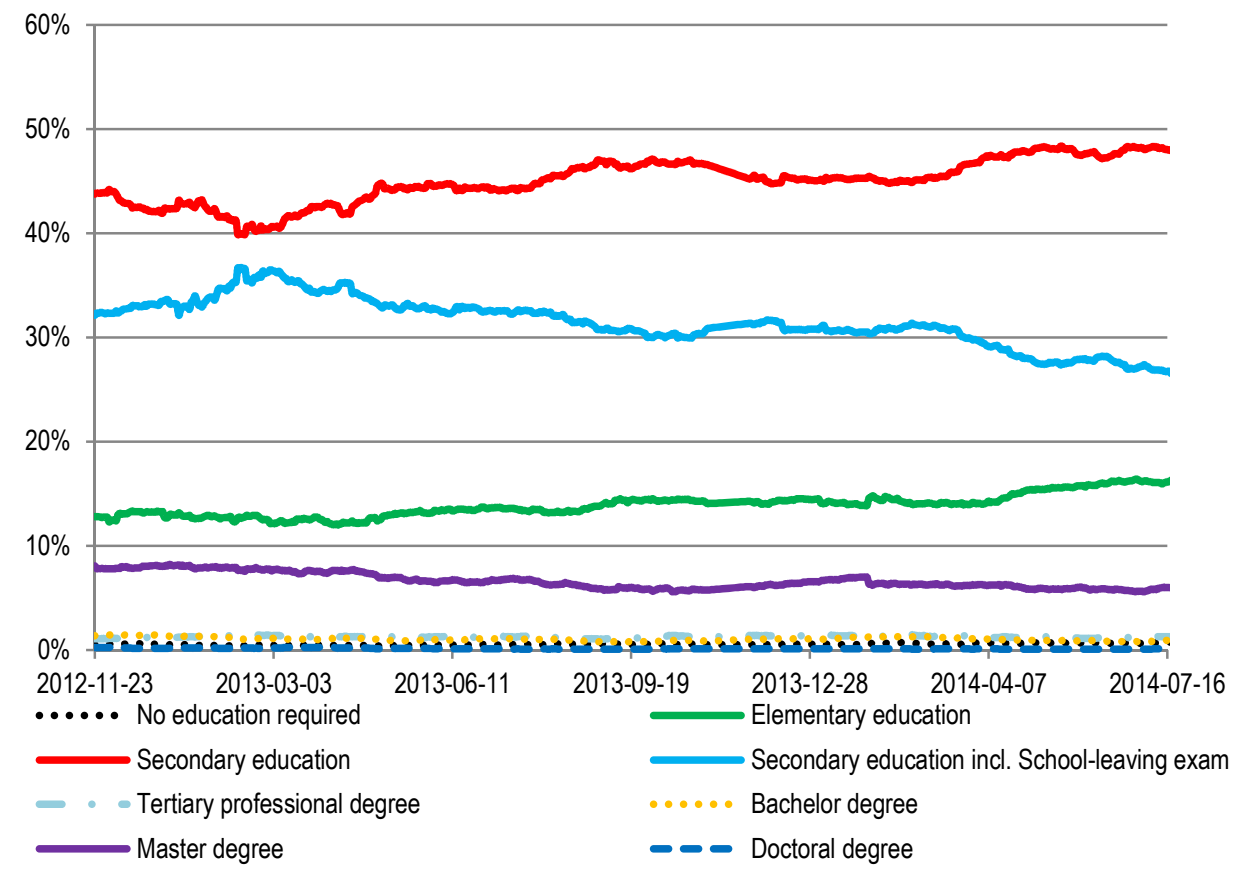

Source: Own work.

According to the figure 5, the demand for workers, who have completed the secondary education with school leaving exam or higher is decreasing. This could have been caused by the increasing demand for labour in the secondary sector, in the production and manufacturing in particular. A detailed overview of the level of education required within the analysed offers is presented in the following table, including the annual changes in demand.

Even though the amount of job offers requiring at least secondary education finished by a school leaving exam decreases, the postulate of positions requiring higher level of education being awarded a higher starting salary is still valid. On a nation-wide average, graduates of master study programs are offered a starting salary of CZK 28,222. In direct comparison, positions requiring only the elementary education are awarded CZK 11,756 on average. Secondary education not finished by a school leaving exam is sufficient mainly in traffic, culture and sport, trade and traffic, construction, production and manufacturing, and agriculture and forestry. Secondary education finished by a school leaving exam is the minimum requirement for getting a job mostly in the administration, finances, IT, and management. Professional tertiary education or university education is especially required in the high-responsibility professional domains like research and development, legal services, education, healthcare, and management. Most of the job offers in agriculture and forestry require only elementary or secondary level education. 


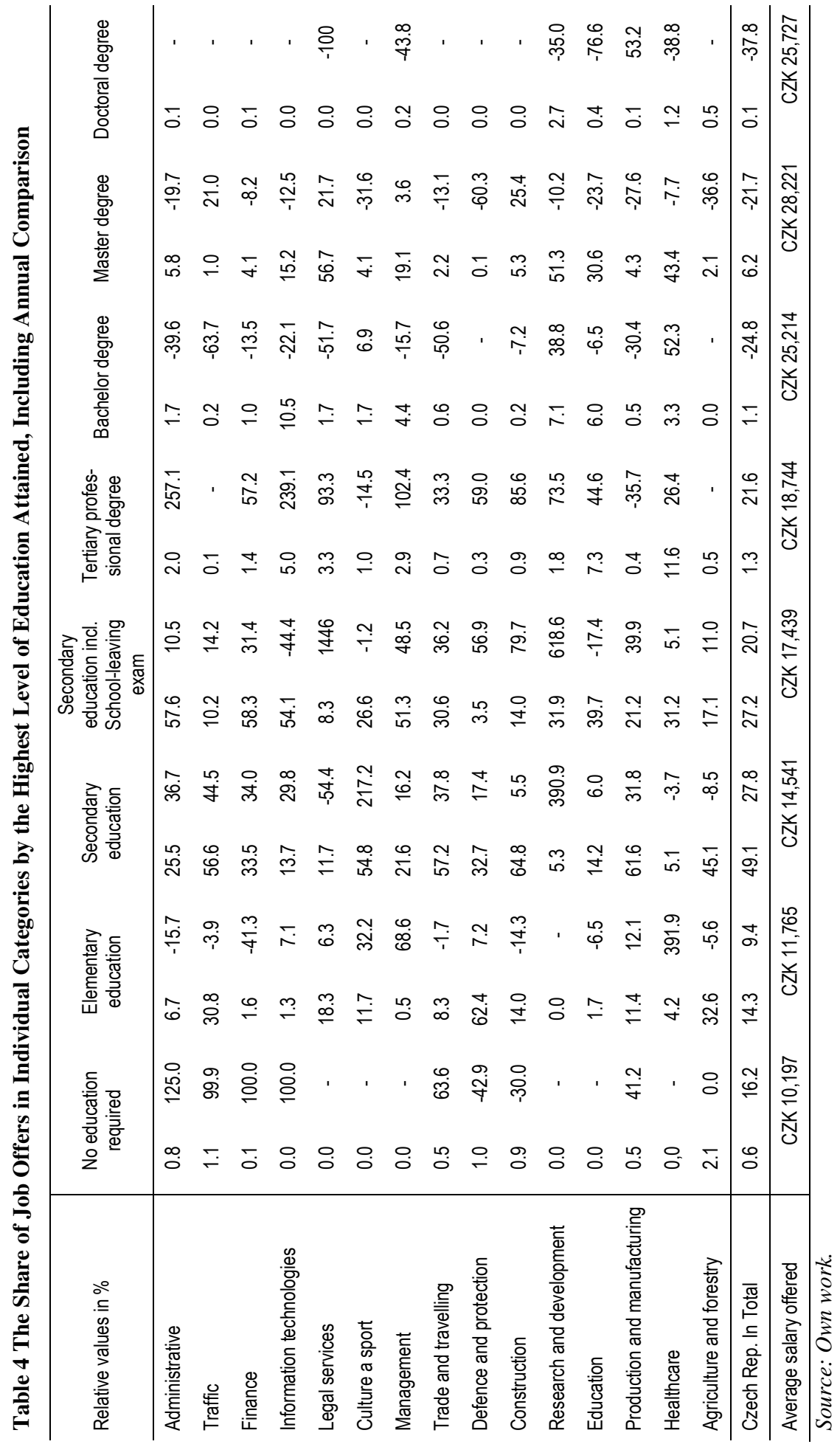


Besides the general requirement for education level attained, employers usually require many other qualifications and personal skills. Employees possessing these skills can expect a higher starting salary. Driving license and basic computer skills are some of the most common skills required by employers. People who can work with computer can thus in average expect to get the starting salary of CZK 19,747, while having the driving licence helps to increase the salary to CZK 18,044. The average minimum salary is higher by $21 \%$ if computer skills are required, while driving licence increases the initial offer by additional $9 \%$ compared to job offers which do not require such a skill. This means that education and knowledge open doors to choice from larger amount of vacant positions and help minimize risks of being unemployed (Riddell 2011).

In combination with the current state of economy, level and specialization of education attained can significantly influence employability on local market. A research studies from Greece suggest the people educated in fields directly connected to private sector, have higher chances of being employed than those who have education in fields which directly support operations of the public sector. (Livanos 2010)

\section{Language Skills}

Different specializations require a very distinct set of personal skills and abilities. Besides those mentioned previously, there is but one more factor which is comparable throughout all of the occupational fields - knowledge of foreign languages. The required knowledge of languages is presented in the following diagram.

\section{Figure 7 Required Language Skills as Occurring in Job Offers}

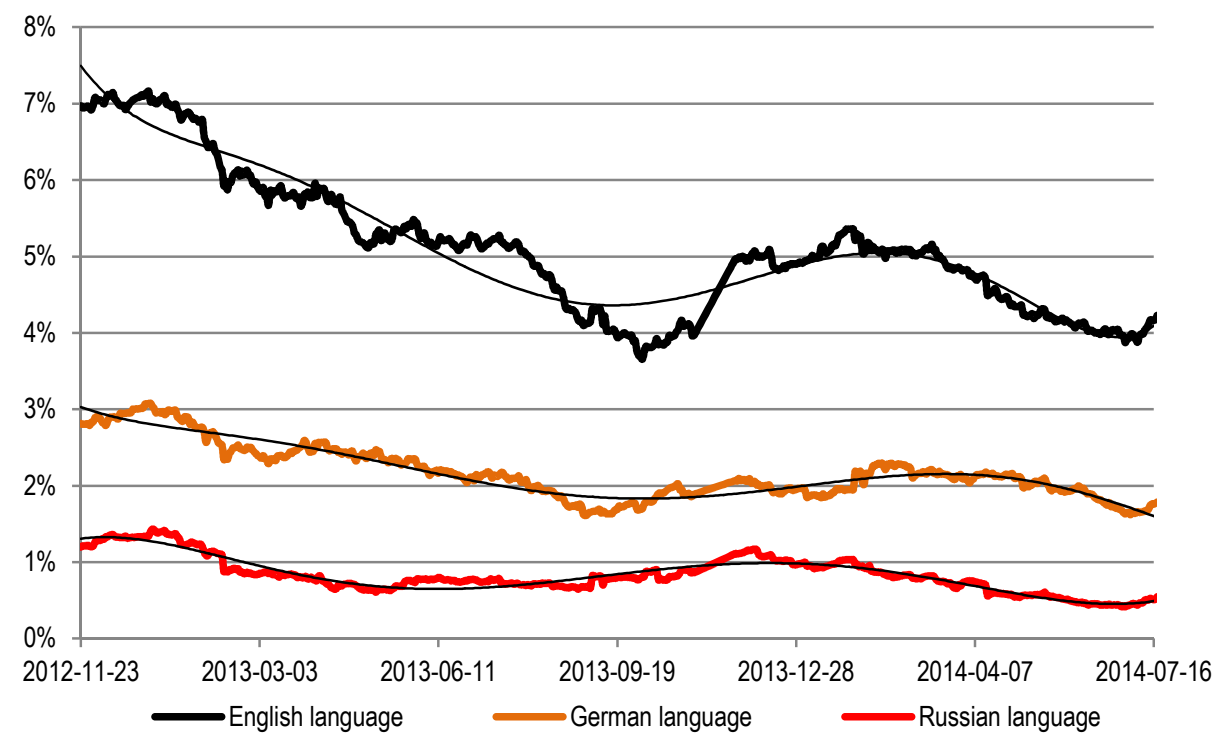

Source: Own work. 
This statistics include only those positions offered, where knowledge of languages is one of the necessary pre-conditions for being eligible to get the job. Besides the listed, many of the positions offered consider such skill to be an advantage. Nonetheless, collecting such kind of data would be technically difficult. The following table presents the distribution of foreign language knowledge required among individual offers, broken down into occupational fields:

Table 5 Relative Share of Language Skills Requirements by Occupation Fields

\begin{tabular}{l|cccccc}
\hline \multirow{2}{*}{} & \multicolumn{2}{|c}{ English } & \multicolumn{2}{c}{ German } & \multicolumn{2}{c}{ Russian } \\
& 2013 & Annual Change & 2013 & Annual Change & 2013 & Annual Change \\
\hline Administrative & $9.56 \%$ & $-33.02 \%$ & $4.78 \%$ & $-27.90 \%$ & $1.59 \%$ & $-24.77 \%$ \\
Traffic & $2.56 \%$ & $-53.70 \%$ & $3.46 \%$ & $-35.20 \%$ & $1.32 \%$ & $-18.89 \%$ \\
Finance & $5.15 \%$ & $-23.27 \%$ & $1.85 \%$ & $-15.71 \%$ & $0.95 \%$ & $-7.37 \%$ \\
Information technologies & $25.46 \%$ & $-24.18 \%$ & $2.10 \%$ & $-57.17 \%$ & $3.15 \%$ & $-32.37 \%$ \\
Legal services & $15.00 \%$ & $190.00 \%$ & $3.33 \%$ & $93.33 \%$ & $1.67 \%$ & $-3.33 \%$ \\
Culture a sport & $3.79 \%$ & $-55.21 \%$ & $1.38 \%$ & $-51.13 \%$ & $2.07 \%$ & $-35.86 \%$ \\
Management & $13.56 \%$ & $-9.41 \%$ & $4.74 \%$ & $-11.89 \%$ & $5.72 \%$ & $15.72 \%$ \\
Trade and traffic & $5.12 \%$ & $-26.22 \%$ & $2.43 \%$ & $-28.06 \%$ & $1.20 \%$ & $-0.18 \%$ \\
Defence and protection & $0.77 \%$ & $-4.62 \%$ & $0.13 \%$ & - & $0.00 \%$ & $-100.00 \%$ \\
Construction & $1.27 \%$ & $-41.39 \%$ & $0.85 \%$ & $6.06 \%$ & $1.06 \%$ & $-33.71 \%$ \\
Research and development & $30.09 \%$ & $5.31 \%$ & $4.42 \%$ & $-13.27 \%$ & $6.19 \%$ & $-13.27 \%$ \\
Education & $12.50 \%$ & $-20.22 \%$ & $0.86 \%$ & $-62.59 \%$ & $0.86 \%$ & $-53.23 \%$ \\
Production and manufacturing & $4.38 \%$ & $-32.27 \%$ & $1.81 \%$ & $-45.53 \%$ & $0.68 \%$ & $-19.17 \%$ \\
Healthcare & $3.01 \%$ & $-38.39 \%$ & $1.23 \%$ & $71.38 \%$ & $1.92 \%$ & $21.18 \%$ \\
Agriculture and forestry & $1.04 \%$ & $-26.08 \%$ & $0.00 \%$ & $-100.00 \%$ & $0.00 \%$ & $-100.00 \%$ \\
\hline Czech Rep. In Total & $5.09 \%$ & $-28.43 \%$ & $2.01 \%$ & $-30.69 \%$ & $1.09 \%$ & $-19.36 \%$ \\
\hline Source: Own work. & & & & & &
\end{tabular}

Source: Own work.

The languages prominent in job offers in the Czech Republic include English, German, and Russian. The analysis clearly shows that English is especially important for getting a job in research and development, and in IT. German language is typically required in administration, Russian in research and development, and in management, too. Other required languages can be ranked in the following order: Polish, Spanish, French, Italian, and Hungarian. In annual comparison, the amount of job offers requiring foreign languages have declined significantly, however, this tendency matches the previous findings of this research which point out the increasing labour demand in production and manufacturing, where the international communication skills are typically only advantageous.

The average minimum salary in job offers which require from the candidates to possess a set of language skills is higher than the total average salary calculated without any 
further qualification assumption. In absolute numbers, positions requiring knowledge of English are offered with an average starting salary of CZK 24,138, whilst a German speaker can expect an average starting salary of CZK 21,463, and the Russian language command contributes to an average starting salary of CZK 25,891. In comparison to job offers requiring no specific language skills, the average minimum salary is thus $39 \%$ higher in job offers where knowledge of English is required. The knowledge of German language leads to a minimum average salary higher by $19 \%$, while job offers requiring Russian promise even a significant $70 \%$ increase in comparison to the average.

\section{Shift Operation}

Organization of work hours is an important factor, which can influence if a person applies for a work positions. The following graph studies the shift operation scenarios occurring in job offers.

\section{Figure 8 Shift Operation as Occurring in the Analysed Set of Job Offers}

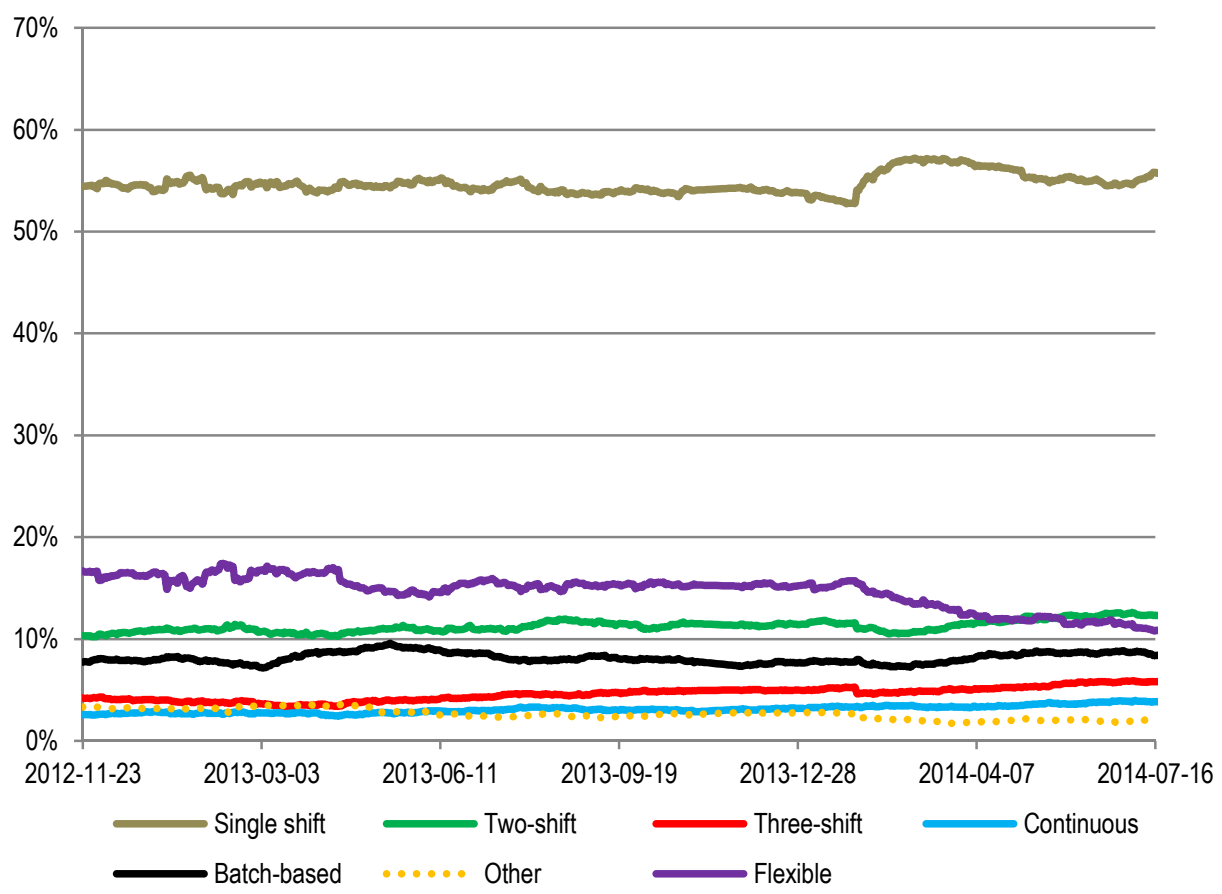

Source: Own work.

The graph provided above shows that the structure of labour market as categorised by the types of shift operation is stable. Most of the offers are placed by companies that operate in the one-shift organisation - approximately 54\%. This can be understood as a 
regular time employment scenario. Flexible work hours are second in order, which signifies the emphasis on results rather than rigid organisational structures. Two-shift organisation with a share higher than $11 \%$ is the third most common scenario occurring in job offers. The structure of job market differentiated by the shift scenarios is presented in the following table, including the relative annual changes.

Table 6 The Shift Operation Scenarios by Occupational Fields

\begin{tabular}{|c|c|c|c|c|c|c|c|c|c|c|c|c|c|}
\hline \multirow{2}{*}{$\begin{array}{c}\text { Relative shares } \\
\text { in } \%\end{array}$} & \multicolumn{2}{|c|}{ Single shift } & \multicolumn{2}{|c|}{ Two-shift } & \multicolumn{2}{|c|}{ Three-shift } & \multicolumn{2}{|c|}{ Continuous } & \multicolumn{2}{|c|}{ Batch-based } & \multicolumn{2}{|c|}{ Flexible } & \multirow{2}{*}{$\begin{array}{c}\begin{array}{c}\text { Oth- } \\
\text { er }\end{array} \\
2.4\end{array}$} \\
\hline & 78.3 & 6.0 & 3.8 & -17.6 & 0.8 & 106.0 & 1.0 & -10.7 & 0.8 & 3.0 & 13.0 & -9.1 & \\
\hline Traffic & 46.8 & -3.2 & 7.1 & 41.0 & 4.8 & 53.9 & 3.3 & 20.1 & 7.8 & -3.2 & 23.9 & -8.6 & 6.2 \\
\hline Finance & 53.0 & -8.7 & 1.5 & 32.8 & 0.2 & 22.6 & 0.2 & 9.0 & 3.1 & 27.1 & 40.6 & 14.6 & 1.4 \\
\hline $\begin{array}{l}\text { Information } \\
\text { technologies }\end{array}$ & 64.6 & -3.5 & 3.4 & -0.6 & 1.3 & 7.1 & 0.5 & 7.1 & 0.3 & - & 27.8 & 9.1 & 2.1 \\
\hline Legal services & 86.7 & 25.7 & 1.7 & -51.7 & 0.0 & - & 1.7 & -75.8 & 0.0 & -100 & 8.3 & -39.6 & 1.7 \\
\hline Culture a sport & 30.3 & -5.9 & 6.2 & -3.8 & 0.0 & - & 0.3 & - & 5.2 & 16.6 & 53.8 & 2.6 & 4.1 \\
\hline Management & 60.1 & 17.5 & 10.6 & 69.9 & 0.8 & 87.4 & 1.1 & 293.5 & 0.5 & -69.3 & 23.4 & -35.7 & 3.4 \\
\hline $\begin{array}{l}\text { Trade and } \\
\text { traffic }\end{array}$ & 40.1 & 0.5 & 11.8 & 14.4 & 1.5 & 36.1 & 1.2 & 0.7 & 18.1 & -9.4 & 22.0 & -4.0 & 5.4 \\
\hline $\begin{array}{l}\text { Defence and } \\
\text { protection }\end{array}$ & 33.3 & 0.3 & 18.8 & -26.5 & 0.9 & -49.4 & 18.3 & 17.2 & 15.4 & -4.6 & 8.8 & 71.4 & 4.4 \\
\hline Construction & 79.8 & -2.3 & 2.3 & 7.5 & 1.5 & -40.9 & 1.4 & 9.7 & 2.1 & 85.6 & 10.7 & 9.0 & 2.2 \\
\hline $\begin{array}{l}\text { Research and } \\
\text { development }\end{array}$ & 75.2 & -1.7 & 0.9 & -56.6 & 2.7 & 30.1 & 1.8 & 73.5 & 0.0 & - & 17.7 & 8.4 & 1.8 \\
\hline Education & 68.1 & -8.8 & 8.2 & 122.1 & 0.0 & 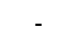 & 2.2 & 133.8 & 1.3 & -6.5 & 16.8 & 1.3 & 3.4 \\
\hline $\begin{array}{l}\text { Production and } \\
\text { manufacturing }\end{array}$ & 58.5 & -2.4 & 16.1 & 0.9 & 12.5 & 16.8 & 3.0 & 6.3 & 1.3 & 6.9 & 6.5 & -6.0 & 2.1 \\
\hline Healthcare & 69.1 & 2.7 & 7.3 & 57.7 & 2.9 & -16.7 & 10.9 & 29.1 & 2.2 & -15.4 & 5.6 & -24.9 & 2.1 \\
\hline $\begin{array}{l}\text { Agriculture and } \\
\text { forestry }\end{array}$ & 52.8 & -8.8 & 21.8 & 29.4 & 2.1 & -11.3 & 1.6 & 232.6 & 3.1 & 10.9 & 12.4 & 10.9 & 6.2 \\
\hline $\begin{array}{l}\text { Czech republic } \\
\text { in total }\end{array}$ & 54.0 & -1.3 & 11.3 & 7.3 & 5.0 & 22.0 & 3.1 & 16.7 & 7.6 & -4.9 & 15.5 & -4.4 & 3.6 \\
\hline
\end{tabular}

Source: Own work.

The one-shift employment scenario is most common in the vast majority of studied occupational fields. The exceptions are the individual performance oriented branches of culture and sport, where more than $53 \%$ of all the vacant positions offer flexible work hours. Such a work scenario is also common in more than $40 \%$ of all the offers in the field of finances. It can be assumed this is connected to the fact that fixed term contracts are signed frequently in this field, and the actual workers are usually self-employed. 


\section{Conclusion}

This research provides unique insights into the characteristics of job offers as occurring in the real recruiting campaigns on the labour market. This research is thus bound to identify interesting facts and propose hypotheses, which can be subject of a consequent studies. The recent quarters have shown the increasing numbers of job offers occurring in the production and manufacturing, which corresponds to the findings of the Czech Statistical Office about the improving performance of the Czech economy. This development also influences the entire structure of labour demand where the total number of positions requiring primary and secondary education only has been growing steadily. The long term average minimal salary as presented in the analysed job offers is still stagnating in the long term, while the average salary offered is decreasing, presumably because of the excessive workforce available. This excess of workforce is caused by relatively higher unemployment than in previous periods, and by the lingering influence of the economic crises.

This study presented the possibility to study the tendencies on the labour market using the short-term, concurrent data. Such approach could be much more flexible than the current ex-post analysis of the labour market data, often conducted with several years of delay. If the actual requirements of the labour market were taken into account by the public authorities which determine how prosperous employees prepare for their engagement in labour market, the ongoing tendencies on the labour market could be addressed in a much more flexible way to allocate more of the available workforce. By automating the process of a preliminary analysis of the opened vacancies, the labour market prognoses could be fine-tuned, and thus the short-term employment tools, such as requalification courses or work force reallocation, can be utilized much more efficiently.

This article presents the unique set of job offers data aggregated from various sources. The information about the vacant job positions can naturally be acquired from variety of specific job portals in the Czech Republic, as well as in other countries. However, the majority of these sources rely purely on its own dataset. The aggregation of these sources is thus highly desirable to gather the dataset suitable for relevant analysis. Public authorities should analyse regularly the present situation at labour market over available data and integrate them flexibly into short and long term employment strategies. In the Czech Republic, the Ministry of Labour and Social Affairs currently presents a monthly unemployment statistics, typically with a one-month delay. However, these statistics contain only an overall account of job positions available, differentiated by regions and education level required. The structure of available job positions could obviously be presented in a more precise way. An inspiration can be found in the Slovak Central Office of Labour, Social Affairs and Family, which breaks down the job offers by detailed requirements for the vacant positions.

\section{References}

ATTERTON, J. (2007). The 'Strength of Weak Ties': Social Networking by Business Owners in the Highlands and Islands of Scotland. Sociologia Ruralis. 47, pp 228-245. DOI: 10.1111/j.1467-9523.2007.00435.x. ISSN: 1467-9523. 
BOJNEC, S., DRIEWS, L., SWINNEN, J. F. M. (2003). Human Capital and Labor Flows Out of the Agricultural Sector: Evidence from Slovenia. Conference Proceedings of International Association of Agricultural Economists, 2003 Annual Meeting, August 16-23, Durban, South Africa, pp 649-654.

BOJNEC, S. (2005). Causes of Changes in Agricultural Employment in Slovenia: Evidence From Micro-data. Journal of Agricultural Economics. pp. 399-416. ISSN 0021$857 \mathrm{X}$.

DARPEIX, A., BIGNEBAT, C., PERRIER-CORNET, P. (2014). Demand for Seasonal Wage Labour in Agriculture: What Does Family Farming Hide?. Journal of Agricultural Economics. 65, pp 257-272. DOI: 10.1111/1477-9552.12019. ISSN: 1477-9552.

DE HOYOS, M., GREEN, A. E. (2011). Recruitment and retention issues in rural labour markets. Journal of Rural Studies. Vol.27 (No.2), pp. 171-180. ISSN 07430167.

CR. (2004, May). Zákon č. 435/2004 Sb. o zaměstnanosti. Sbírka zákonů České republiky.

CR. (2011, Nov). Předpis č. 367/2011 Sb. - zákon, kterým se mění zákon č. 435/2004 Sb., o zaměstnanosti, ve znění pozdějších předpisů, a další související zákony. Sbírka zákonů České republiky.

CR. (2011, Nov). Předpis č. 390/2011 Sb. - vyhláška, kterou se mění vyhláška č. 518/2004 Sb., kterou se provádí zákon č. 435/2004 Sb., o zaměstnanosti, ve znění pozdějších předpisů. Sbírka zákonů České republiky.

CR. (2011, Feb). Zákon č. 73/2011 Sb. o Úřadu práce České republiky a o změně souvisejících zákonů. Sbírka zákonů České republiky.

CSO. (2014, April 30). Analýza: Postavení českého trhu práce v rámci EU. Retrieved May 30, 2014, from http://www.czso.cz/csu/csu.nsf/informace/czam043014analyza14.doc.

CSO. (2014, Mar 11). Komentár̆: Vývoj na trhu práce ve 4. čtvrtletí 2013. Retrieved May 30, 2014, from http://www.czso.cz/csu/csu.nsf/informace/cpmz031114analyza14.docx.

CSO. (2012, Dec). Počet evidencí na úřadech práce podle sekcí odvětvové klasifikace ekonomických činností (CZ-NACE) k 31. 12. 2011, Cizinci v ČR 2012. Retrieved Dec 23, 2013, from http://www.czso.cz/csu/2012edicniplan.nsf/kapitola/1414-12-r_20120900 .

GOODWIN, B.K., HOLT, M.T. (2002). Parametric and Semiparametric Modeling of the Off-Farm Labor Supply of Agrarian Households in Transition Bulgaria. American Journal of Agricultural Economics. Vol. 84, No. 1, pp. 184-209. ISSN 1467-8276.

HODGE, I., DUNN, J., MONK, S., FTIZGERALD, M. (2002). Barriers to participation in residual labour markets. Work, Employment and Society. 16, pp. 457-476. ISSN 1469-8722. 
MoLSA Integrated portal. (2014), Měsíční statistika nezaměstnanosti za rok 2013, Statistiky nezaměstnanosti, Retrieved Jul 23, 2014, from http://portal.mpsv.cz/sz/stat/nz/mes.

JANSEN, M., FELGUEROSO, F., FUENTES, A., WÖLFL, A. (2013). Youth Labour Market Performance in Spain and its Determinants. OECD.

JOHNSON, T.G. (1991). The Market for Farm Family Labor in Multiple Job-Holding Among Farm Families, ed. M.C. Hallberg, J.L. Findeis \& D.A. Lass. Ames: Iowa State University Press.

LESCHKE, J. (2012). Has the economic crisis contributed to more segmentation in labour market and welfare outcomes?. European Trade Union Institute. 2012. ISSN 1994-4454.

LINDSAY, C., MCCRACKEN, M., MCQUAID, R.W. (2003). Unemployment duration and employability in remote rural labour markets. Journal of Rural Studies. 19, pp. 187200. ISSN 0743-0167.

LIVANOS, I. (2010). The relationship between higher education and labour market in Greece: the weakest link?. Higher Education. pp. 473-489. ISSN 0018-1560.

RIDDELL, W. C., SONG, X. (2011). The impact of education on unemployment incidence and re-employment success: Evidence from the US labour market. Labour Economics. 18.4, pp. 453-463. ISSN: 0927-5371.

SCHNICKE, H., HAPPE, K., SAHRBACHER, C. (2007). Structural Change and Farm Labour Adjustments in a Dualistic Farm Structure: A Simulation Study for the Region Nitra in Southwest Slovakia. Leibniz Institute of Agricultural Development in Central and Eastern Europe. ISSN 1438-2172.

TEAGASC. (2011). Deliverable 9.1: Defining an Institutional Framework for the Labour Market - Based on Literature Review.

TOCCO B., DAVIDOVA S., BAILEY A. (2012). Key Issues in Agricultural Labour Markets. Factor Markets. No. 20. ISSN: 978-94-6138-191-0.

UZZI B. (1997). Social structure and competition in interfirm networks: The paradox of embeddedness. Administrative Science Quarterly. Vol. 42, pp. 35-67. ISSN: 0001-8392.

VAN DER HOEVEN, R. (2010). Labour markets trends, financial globalization and the current crisis in developing countries. UN.

VAN HERCK, K. (2009), Deliverable 7.4: A Comparative Analysis of Rural Labour Markets. Retrieved Jul 25, 2014, from http://www.scarled.eu/uploads/media/SCARLED_D7.4.pdf. 